HSTC Bulletin

Journal of the History of Canadian Science, Technology and Medecine

hstc

Revue d'histoire des sciences, des techniques et de la médecine au Canada

bulletin

\title{
The 1978 Ontario Mental Health Act in Historical Context
}

\section{Frances Frankenburg}

Volume 6, numéro 3 (22), septembre-september 1982

URI : https://id.erudit.org/iderudit/800144ar

DOI : https://doi.org/10.7202/800144ar

Aller au sommaire du numéro

Éditeur(s)

HSTC Publications

ISSN

0228-0086 (imprimé)

1918-7742 (numérique)

Découvrir la revue

Citer cette note

Frankenburg, F. (1982). The 1978 Ontario Mental Health Act in Historical Context. HSTC Bulletin, 6(3), 172-177. https://doi.org/10.7202/800144ar

Copyright (C) Canadian Science and Technology Historical Association / Association pour l'histoire de la science et de la technologie au Canada, 1982
Ce document est protégé par la loi sur le droit d'auteur. L'utilisation des services d'Érudit (y compris la reproduction) est assujettie à sa politique d'utilisation que vous pouvez consulter en ligne.

https://apropos.erudit.org/fr/usagers/politique-dutilisation/ 


\title{
RESEARCH NOTE/NOTE. DE RECHERCHE
}

\author{
THE 1978 ONTARIO MENTAL HEALTH ACT
}

\author{
IN HISTORICAL CONTEXT
}

Frances Frankenburg*

(Received 12 March 1982. Revised/Accepted 25 October 1982.)

The controversy surrounding the new legislation in ontario dealing with involuntary hospitalization of the mentally ill -the 1978 Mental Health Act (RSO, 1970, Chap. 269; 1978, Chap. 50) -- is rooted in the history of Ontario's management of the mentally ill. To appreciate the debate within its historical context, the history of confinement of the mentally ill in Ontario will be briefly reviewed, and then the current Mental Health Act will be discussed.

Until the middle of the nineteenth century the mentally ill in Upper Canada were either cared for at home, or placed in country jails. 1 By the 1830 s there was, however, a growing realization of the needs of the handicapped members of society. In 1839 the Legislature of Upper Canada passed a resolution authorizing money for the erection of a 'lunatic asylum.' No progress was made until 1841, when a jail, considered unfit for prisoners, was converted into a temporary asylum. A person was admitted into the asylum if certified by three physicians as mentally ill. The building was as unsuitable for an asylum as it had been for a prison, and seems to have had an incompetent and chaotic administration. J.H. Tuke, a great-grandson of William Tuke (who had been extremely active in the English reform of the asylum) visited the jail-cum-asylum in 1845 and wrote:

It is one of the most painful and distressing places I have ever visited ... There were, perhaps, 70 patients, upon whose faces misery, starvation, and suffering were indelibly impressed. The doctor pursues the exploded system of constantly cupping, bleeding, blistering, and purging his patients; giving them also the smallest quantity of food, and that of the poorest quality ... The doctor, in response to my question, and evident disgust, boasted that he employs no restraint, and that his cures are larger than those in any English or continental asylum.

There was pressure on the asylum from its beginning to be a custodial institution only. The municipalities transferred their indigents to the asylum which had the advantage, from their point of view, of being provincially funded. Mental health acts passed in the late 1800 s were partially efforts to

* Mailman Research Center, McLean Hospital, 115 Mill St., Belmont, MA 91178, USA. 
prevent the asylum from becoming a boarding house for the municipalities' dependents, or to create the Canadian equivalent of English 'workhouses' or German Zuchthausern.

As immigration and industrialization increased in Upper Canada, the number of people needing institutional care grew, the asylums became more crowded and the quality of care decreased. Between 1870 and 1884 the London Lunatic Asylum was built. By the turn of the century it had over 1,000 patients and was the third largest asylum on the continent. Public tolerance for the mentally ill waned; at the beginning of the nineteenth century they were seen as 'unfortunates,' but by the end of the century they were seen as foreign paupers or as degenerates who had masturbated themselves into insanity. 3

In the early 1900s there was a revival of medical interest in the mentally ill. Hopes were raised that medical and treatable causes would be found for all mental diseases. However, there was little change within the Ontario institutions, and most ontario mentally ill patients were involuntary in the early 20 th century. The overcrowding, understaffing and stigma of the large institutions attracted few voluntary patients. In 1922, of the 2,133 patients in the Ontario Hospitals (the new 'medical' name for the asylums), only seven were voluntary. 4

Throughout the next decades there was continuing modification of commitment legislation in Ontario. The overall trend was to recognize insanity as a mental illness, and commitment as a medical procedure. In 1930 for example the mental hospitals were removed from the department of the provincial secretary and placed within the department of health. Dr Kenneth Gray, a physician and lawyer, formulated the 1935 Mental Hospitals Act and emphasized the need to treat the mentally ill, rather than to control their behaviour. He saw the previous legislation as too restrictive:

Early statutes show a pre-occupation with safeguarding the subject against improper or malicious incarceration. As this danger is seen to be more apparent than real, the legislation becomes less concerned with the erection of formidable legal barriers against admission and more concerned in making the way of admission smooth for the person in need of treatment. 5

Commitment became simpler under the 1935 Act. One physician could commit a person for thirty days in an 'examination unit.' Indefinite commitment to an Ontario Hospital still required the signatures of two physicians. The assumption was that if involuntary hsopitalization could be achieved more rapidly, then it could prevent deterioration of that person's mental state. 6 The terminology of the Act was more 'medical' than that of its predecessors. People who formerly were described as 'insane and dangerous to be at large' and 'idiots' were now described as 'mentally ill' or 'mental defectives.'

Conditions in the Ontario Hospitals deteriorated during World War II because of diversion of staff, money and actual building 
space to the military. ${ }^{7}$ Once again mentally ill people were kept in jails for lack of more suitable accommodation. In 1948 the conditions were described in this way:

Patients were ... retained in locked wards. Because
of the understaffing and overcrowding, the emphasis
was on custody rather than therapy. Patients and
their relatives used the hospital only as a last
resort. Mental illness evoked feelings of shame
and hopelessness in the families of the mentally
ill; many were encouraged to forget the patient
following his admission.8

In the last three decades the atmosphere surrounding the management of the mentally ill has changed once more. The population of patients in mental hospitals has decreased, due if Coincident with this change there has been a growing emphasis on community psychiatry, with the aim of outpatient treatment. Criteria for commitment have become more restrictive. In the 1960 Ontario Mental Health Act the physician could commit a person for 'observation, care, and treatment.' This was known as the welfare standard. In 1967 the Act was revised, and a safety standard instituted. A physician could then commit a person only 'in the interests of his own safety or the safety of others.' Ontario physicians interpreted the Act in different ways. Some committed people only if they were suicidal or homocidal, others if there was any risk to the person's financial or social status. II In 1978 the Mental Health Act was again revised, and it is this Act with which there is so much concern today.

Under the 1978 Mental Health Act there are two types of involuntary hospitalization: detention and commitment. Detention is for a maximum of 120 hours and ensures an inpatient psychiatric assessment. It is initiated by one doctor completing an 'Application for Psychiatric Assessment,' a 'Form 1.' The form allows the physician some latitude. He only has to think that the person is 'apparently' mentally disordered but that because of this possible disorder serious bodily consequences to that person or another are 'likely' to result. The period of 120 hours allows a second physician to see the patient even in the most outlying parts of ontario.

Once the person is detained, the attending physician in the psychiatric facility will assess the person. The physician may discharge him, or he may decide that hospitalization should be prolonged. If however the patient continues to refuse to stay in the facility, the second physician may commit that patient by completing a 'Certificate of Involuntary Admission,' a 'Form 3.'

The doctor completing the 'Form 3' must not be the same one who had completed the 'Form 1.' This requirement is a safeguard against inappropriate commitment. Another safeguard is the availability of review procedures. The patient, or anyone acting on his behalf, may ask for his status as a committed patient to be reviewed by a review board when he is first 
committed, or when a certificate of commitment is renewed. There is an automatic review process on the completion of a fourth certificate of renewal as another safeguard against unnecessarily prolonged commitments.

As well, all certificates of involuntary admission are forwarded to the officer-in-charge of the psychiatric facility, who himself will review the admission. The person may apply for habeas corpus, and he may make repeated applications to the review board.

Since 1973 there have been at least six independent studies of commitment procedures in Ontario. In each study the certificates themselves were examined, and 80-908 found unsatisfactory. 12 Many of the responses were meaningless, silly or illegible. This failure to comply with documentation procedure may be more than just carelessness. Physicians often committed people giving reasons that were more in fitting with Gray's 1935 Act. They committed people if they needed 'care, supervision, and control,' not because serious bodily harm was likely to result. 13

Ontario psychiatrists criticize the current act. Miller, for example, 14 describes, among other cases, a hypomanic lawyer jeopardizing his job because of his illness. He 'should have been kept in hospital against his will, but, under the terms of the Mental Health Act, clearly could not be.' He also noted that the 'Act may lead to incomplete treatment' by allowing a patient to leave the hospital after some improvement without complete stabilization or sufficient rehabilitation.

McCormick 15 also describes four cases of serious deficiencies in medical care because of the need to cite imminence of harm. Menuck and Littmann however defend the Act, noting that in their experience the Act has not 'obstructed good clinical care and treatment and may, in fact, be salutary to the management of patients.'16

Some argue that the Act continues, as did preyious ones, to give far too mach power to the psychiatrist, 17 and that the psychiatrist's decision to commit a person is not based on his medical knowledge, but rather on his allegiance to the prevailing social order (see e.g. Foucault 18 and Goffman ${ }^{19}$ ), and that commitment should be removed from the medical sphere. Lawyers, social workers, and other professionals who might be involved in the place of physicians are not usually present in hospital emergency rooms. It is unusual, and not likely to be accepted by the medical profession, for nonmedical people to decide about admissions, whether voluntary or nonvoluntary, into hospitals.

Commitment will probably continue to be a medical decision for these reasons -- and the weight of inertia -- but the review board procedure serves as a powerful and necessary check on the medical practice. Although physicians have a natural dislike for judicial or legal 'interference' in their work, the need for legal regulation of the infringement on the civil rights of a person is clear. At the same time, as vincent points out: 
For the mentally ill, the greatest threat is actualizing their civil rights is mental illness, not involuntary hospitalization. The mentally ill may live in the community, but be "incarcerated" by their psychosis. 20

The history of the involuntary hospitalization of the mentally ill is marked by ignorance and cruelty. In the last three centuries the greater sensitivity to individuals' rights has led to an improvement in the conditions of the confinement. There have been advances in psychiatric knowlege recently, and physicians in Ontario now see confinement not just as a way of keeping the insane locked away, but rather as a means of caring for the person and as a prelude to possible treatment.

If a physician thinks that a person is probably suffering from a mental disorder which may lead to imminent serious physical harm, then, and only then, under the current ontario legislation, can he hospitalize the person against his will. A single physician can detain a person for 120 hours. Periods of involuntary hoppitalization longer than this must be authorized by a second physician and are subject to review by provincially-appointed review boards.

The civil libertarian claims that the 1978 Mental Health Act in formulating the present criteria for confinement has given the physician too much power. The physician wishes he had yet more. Both distort the history and present conditions of confinement. The libertarian dwells on the horrors of confinement of the past and the limitations of psychiatric expertise, but ignores the presence of mental iliness and modern drugs. The physician in turn forgets the past abuses of commitment, in which physicians often played a part. Involuntary hospitalization is carried out now in Ontario with more decency and professionalism than it has been in the past, partly because of the improvements in modern psychiatric care, and partly perhaps because of the greater reliance on checks by independent bodies.

\section{NOTES}

1. Consult G.C. Price, 'A History of the Ontario Hospital,' (unpublished PhD dissertation, University of Toronto, 1974).

2. Quoted in Fred Ernst, 'Treatment of the Criminally Insane in Ontario, 1830-90,' (unpublished research paper, University of Toronto, 1980), 6 .

3. Rainer Baehre, 'From Pauper Lunatics to Bucke: Studies in the Management of Lunacy in 19th Century Ontario,' (unpublished PhM thesis, University of Waterloo, 1976), 265 .

4. S.J. Pollock, 'Social Policy for Mental Health in Ontario 1930-1967,' (unpublished PhD dissertation, University of Toronto, 1974), 8 . 
5. Kenneth G. Gray, 'The Mental Hospitals Act. 1935. (Ontario),' University of Toronto Law Journal-2 (1937), 103-13.

6. Pollock, op. cit., note 4 .

7. Ibid.

8. Alec Richman, Psychiatric Care in Canada: Extent and Results (Ottawa, 1966), 33.

9. Henry Brill and Robert E. Patton, 'Clinical-Statistical Analysis of Population Changes in New York State Mental Hospitals since Introduction of Psychotropic Drugs,' American Journal of Psychiatry 119 (1962), 20-35.

10. Garfield Tourney, 'A History of Therapeutic Fashions in Psychiatry, 1800-1966,' ibid., 124 (1967), 784-96.

11. David S. Heath, 'Letter to the Editor,' Canadian Journal of Psychiatry 24 (1980), 195-6.

12. Stewart Page and John Firth, 'Civil Commitment Practices in 1977,' ibid., (1979), 329-34.

13. Gilbert Sharpe, 'The Ontario Mental Health Act, 1978,' ibid., 517-19.

14. A. Miller, 'The Ontario Mental Health Act (1978),' ibid., 515-16.

15. William 0. McCormick, 'Involuntary Commitment in Ontario: Some Barriers to the Provision of Proper Care,' Canadian Medical Association Journal 124 (1981), 715-17.

16. M. Menuck and S.K. Littman, 'Involuntary Admission to Hospital and Treatment in Ontario: Is Pessimism Among Physicians Warranted?' ibid., 126 (1982), 1168-71.

17. Raj Anand, 'Involuntary Civil Commitment in Ontario: The Need to Curtail the Abuses of Psychiatry,' The Canadian Bar Review 57 (1979), 250-80.

18. Michel Foucault, Madness and Civilization (New York, 1965).

19. Erving Goffman, Asylums (Chicago, 1961).

20. M.O. Vincent, 'Commentary,' Canadian Journal of Psychiatry 24 (1979), 334-5. 